\title{
CAN WE ENSURE THE INTENDED INTERPRETATION OF AN UTTERANCE?
}

\author{
MILADA HIRSCHOVÁ \\ Charles University Prague \\ Milada.Hirschova@seznam.cz
}

In an inferential model of communication, the "indirectness" is the most prominent and most often pursued feature of utterances (when seen as speech acts) since there is no predictable (default) link between the form and the meaning of an utterance and, the repertory of ways how to "shape" a message to be conveyed into an utterance offers an extensive bundle of pragmatically more or less equivalent outcomes. The importance of context which supplies the interlocutors with the necessary additional information for the interpretation of a unique utterance is indisputable. On the other hand, it is exactly context which can bring a speaker to anticipate all the possible interpretations of what s/he is going to say (together with potential perlocutionary effects) and, as a result of it, make him/her to pay a special attention to the choice of words in order to rule out those inferences and interpretations which are unintended. Being aware of hearer's possible inferences can make a speaker to be quite specific and as direct as possible. (It can be seen as a reverse of politeness strategies - clarity of a message is in the first place and regard to a „face threat" comes after it. It doesn't mean, though, that utterances formed with an effort to be specific and direct always need to be ,bold on-record threatening“.) The interpretation of both really or seemingly explicit utterances (speech acts) and of those which are non-stereotypical and /or non-explicit intentionally includes a/ the interpretation of "what is said" (explicature) and b/ interpretation of "what is meant" (implicature - in all its varieties). The maxim of manner and its submaxims (no matter if observed or if ignored or intentionally broken) seem to be crucial here. Since the fulfillment of speaker's communicative intention depends on the addressee's comprehension of the utterance meaning and his/her recognition of the speaker's illocutionary point the speaker needs to seek ways (means of expression) supporting the satisfactory (intended) interpretation of his/her uttearance and, at the same time, ways to avoid the unintended and undesirable inferences (potential problems) deductible of the utterance. As for the inferential process, it most likely is probabilistic (Levinson 1983: 114-116) and it rarely can be verified - predominantly only in cases when a problem actually arises. The level and imperativeness of speaker's potential problem awarness partly depend on the discourse (in spontaneous interpersonal conversations the urge to correct or specify an utterance can be expected to occur more frequently than, e.g., in an arranged media interview or in a prepared public speech) and on the actual communicative situation, especially on the definition of the addressee or a target group. Our case study has shown that the most general strategy can be described as speaker's 
stressing what his/her utterance is not, i.e. as an effort to rule out the unwanted open ends.

Basically, there can be two varieties of wrong understanding/ incomprehension: a/ concerning the propositional content of an utterance, b/ concerning its illocutionary force. Both assumed types of wrong understanding can bring about unwanted inferences and they can be, from the viewpoint of a speaker, a potential cause of unsuccesful (infelicitious) communication. (At the moment, we do not deal with wrong understanding arising in situations when a language which is not a mother tongue of one or both of the interlocutors is used.) Both types of wrong understanding have their own reasons and, because speakers can perceive that they can occur simultaneously, they may combine specific strategies used as remedial. While the a/ cases can often be mended by providing an additional piece of information, the $b$ / cases can start a series of more or less complicated communicative actions, mostly subsumed under the label of metapragmatic awareness. As was stated above, the use of remedial strategies (corrections, additional subsidiary illocutions, explanations or, as an ultimate means of expression, admissions of misformulation) is more frequent in spontaneous speech; in well prepared speeches or written papers, the use of similar strategies is rare or intentional (as a part of addressee-oriented persuasive activity). Also, anticipation of addressee's potential inferences offers a space for manipulative practices in communication.

In the following, I will deal with the a/group of wrong understanding first and then with the group b/, even though, as the examples have shown, strategies targeted at a/ and b/ can overlap. As for the types of discourse, majority of the examples pertain to interpersonal communication. I will pursue mainly phenomena related to what John Lyons called neustic - the layer of utterance meaning expressing speaker's commitment to acceptability or desirability of the conveyed content (Lyons 1977:749-750) and, as another major topic, the issues related to illocutionary force. Concerning the language examplification, the primary language explored is Czech; nevertheless, the English translations show that in the area in question the usage in both languages, no matter how different and unrelated, have proven strong similarities as for the means of expression of the performed strategies. Among the investigated issues, specifications and ensuring language behaviour can be observed in three main areas: specifications of sentence meaning by metalinguistic negation, specifications concerning illocutionary force expressed by illocutionary verbs and derived nouns and, specifications of illocutionary force through modal verbs and verbal mood. In an interpersonal conversation, misunderstandings are unwanted mainly in exchanges including directives as well as assertives if they convey facts which can be considered in a broad sense inconvenient or sensitive for the addressee - the point is that certain formulations can be perceived as unacceptable, harsh or impolite, therefore, the speaker must "weight his/her words". The same attention is paid to commissives since they create obligations for the speaker.

Anticipation of misunderstanding and of interlocutor's reactions arising from potential unwanted inferences and interpretation may start explicit communicative actions of the kind Let me correct myself, Let me be more exact etc. Nevertheless, the main strategy is rectification, i.e., replacement of problematic or less suitable items by appropriate ones. The replacement can be targeted either at certain components of a proposition or at the indicators of the illocutionary force. 
As soon as the speaker realizes that his/her utterance may be perceived in a way s/he considers undesirable s/he tries to correct the earlier utterance. (When interested in correct interpretation, s/he can try to correct also a previous utterance of another speaker.) An important instrument in the area of content rectifications is the so called metalinguistic negation. In cases like (1) - (3)

(1) Já nezruším svou prednášku, já vás ji ušetřím.

"I will not cancell my lecture, I will spare you from listening to it."

(2) Dnes není venku teplo, je tam vedro.

"It is not worm outside today, it is hot."

(3) Nekoupil si auto, koupil si svi̊j sen.

"He did not buy a car, he bought his dream."

negation does not focus on the truth or falsity of the asserted propositions but on the assertability of an utterance with those propositions at the moment. (The bold types indicate specific stress placement.) What is negated (removed) here is conversational implicatum based on the first and the second submaxims of Manner - "Avoid obscurity of expression", "Avoid ambiguity". One description is cancelled in favour of another, whose contribution to the meaning is more or less identical in a relevant context, but different as for connotations (the possible obscurity or ambiguity of denied expressions is pragmatic, context dependent). In such formulations, assertability in a given context is targeted. As L. Horn comments (Horn 2001:370-377), similar utterances are negative only formally - they are used to object to a previous utterance or as corrections of earlier utterances of the same speaker. They offer speakers a way to announce their unwillingness to assert something in a given way or to accept another's assertion of it in a given way.

Metalinguistic negation can be based also on the first submaxim of Quantity ("Make your contribution as informative as required"):

(4) U zkoušky nepropadli někteří studenti - propadli všichni.

"Some of the students did not fail in the exam - all of them failed."

(5) To nebyla nějaká ženská, to byla jeho žena.

"It was not some/a woman, it was his wife."

In (4), the quantity of information concerns the applied quantificator, cf. scalar implicatures (Levinson $2000: 79-86$ ), in (5), the quantity of information concerns the level of definiteness. In examples (1) - (5), if only the sentence in the first position was uttered, it could be interpreted as a simple statement of the kind "It is not truth that I will cancel my lecture, that it is warm outside, that he bought a car, that some of the students failed, that the person in question was a woman", and, consequently, it also could be presupposed that truth is the opposite: I will give the lecture; it is cold outside; he either did not buy anything or bought something else than a car; some of the students passed the exam; the mentioned person was a man. Suggested (required) re-interpretion on the part of the addressee consists in denial of the meaning of the stressed expression in the first sentence and replacing it by the meaning of the stressed expression of the sentence in the second position. A variation of this rectification strategy occurs when a speaker uses utterances with the mentioned form not as a reaction to something previously asserted but as a specific way how to emphasize, accentuate the very meaning of the expression in the second position. That, too, of course is a way how to be precise in conveying the message and support speakers chances to make himself or herself clear. 
In other situations, specifications and corrections can be targeted at the illocutionary force:

(6) Odjed'! Zmiz odsud! Já ti to nenařizuji, já tě o to prosím.

"Leave! Get out of here! It is not an order, it is a plea."

Correction of this kind can occure either in a situation when the speaker is not in a position of authority enabling to issue orders, or in a role constellation when replacement of an order by a plea can be seen as more urgent because of stressing speaker's emotional involvement, and, therefore, more persuasive towards the addressee. Such an effort may be intensified by adding a "middle degree" directive:

(6') Odjed"! Zmiz odsud! Já ti to nenařizuji, ani tě o to nežádám, já tě o to prosím.

"Leave! Get out of here! It is not an order, it is not even a request, it is a plea."

In order to decide what kind of communicative action is taking place, that is to say, whether the speaker actually (sincerely) tries to impress the addressee's feelings or whether it is just a kind of a communicative manipulation (if the speaker could add $I d o$ not order it to you even though I could, as you know), the analyst always needs to know maximum of details forming the utterance event. Corrections targeted at the illocutionary force are very common if the speaker wants to avoid a strong commitment for him/herself:

(7) Neslibuji vám to, ale pokusím se prijitt.

"I do not promise that to you but I will try to come."

In similar cases, correction of a commisive speech act is often supported by a reference to some infavourable circumstances representing an (objective, on speaker's will independent) obstacle to a real promise so that the addresse need not interpret the correction as a result of speaker's unwillingness:

(7') Neslibuji vám to (protože můj dalši program na ten den je velmi rozsáhlý), ale pokusim se prijít.

"I do not promise you that (because my other program for the same day is very extensive) but I will try to come."

Utterance events in which the speaker feels necessary to make it clear that his/her speech did not perform an order, a promise or some other kind of directive or commitment have in common that either a speaker or an addressee are involved (interested) in the achievement of the illocutionary point.

In the previous paragraph we have shown utterances with illocutionary force negation or correction, i.e. such that - as Nežádám tě, abys odjel / I do not ask you to leave - can be symbolized as $\sim F(p)$ (if we adopt Searle's notation $F$ for the illocutionary force indicator and $(p)$ for the propositional content). In those, negation does not apply to the propositional content. Nevertheless, if we consider the following examples we can see a difference:

(8) Neradim ti, abys tam chodil.

"I do not advise you to go there."

(9) Nedoporučuji ti, abys mu to řikal.

"I do not recommend you to tell him that."

Even though the negation is placed on the performative verb (the F indicator), both (8) and (9) still can function as an advice and a recommendation (they are not performative, though). They only convey a directive NOT to do something, i.e. the negation applies to $(p)$. These examples are pragmatically equivalent to (performative) utterances 
(8') Radim ti, abys tam nechodil.

"I advise you not to go there."

(9') Doporučuji ti, abys mu to neřikal.

"I recommend you not to tell him that."

There are reasons to suppose that the difference between (8), (9) and $\left(8^{\prime}\right),\left(9^{\prime}\right)$ is anchored in their context immersion. The directives are basically considered to be started upon speaker's initiative, they open a sequence of communicative actions (Wunderlich 1976). The speaker's initiative evidently is at the origin of an order, a plea or a request because they pursue speaker's interests in the first place. On the other hand, a non-faulty (sincere) advice or a recommendation are unmarkedly oriented at addressee's best interests and they are often (though not necessarily) sought or asked for, i.e., it is the prospective addressee whose initiative starts the exchange. If an advice or a recommendation is a reaction to some previous speech (probably including a question like What do you think? What is your advice/recommendation?) it is expectable that an echo (in the form of $\left(8^{\prime}\right)$ or $\left(9^{\prime}\right)$ ) will follow because the speaker just complies with the request. If the advice is not overtly asked for, the speaker can stress his/her personal attitude not to advise or not to recommend the action talked about and use (8) and (9). (This, of course is more of a tendency, not a rule.)

Similar pragmatic shift of negation can be seen in (10) and (11):

(10) Nevaruji tě před ukvapeností, ale před zaručenou ostudou.

"I do not warn you about being rash but about a sure disgrace."

(11) Nežádám tě o morální podporu, ale o nějaké penize.

"I do not ask you for your moral support but for some money."

Here, the utterances contain in fact two $(p)$ elements ("addressee being rash", "addressee getting into a trouble", "addressee providing speaker with moral support", "addressee providing speaker with some money". The illocutionary force is not cancelled (the utterances are not performative, though) and the negation applies to the first of ( $p)$ s. At the same time, the second $(p)$ which is not negated, is stressed. While in 1.2. we have seen correction and specification of $F$, an analogy to rectification strategy shown in 1.1. can be seen here.

Rectifications of illocutionary force using modals do not concern only cancellation or weakening of a speech act but also its supporting or enhancing. At the same time, explicit manifestation of will can be relativized by conditional mood (see 2.3 . below).

In the area of directives, it is mostly muset/ potrebovat/ být nucen (need and must) conveying speaker's obligation to perform the particular act and, in that way enhancing its imperativeness:

(12) Musim/ potrebuji se vás zeptat, jestli ...

"I do need to ask you, whether ..."

(13) Musím/jsem nucen vás o něco požádat.

"I must/ I am obliged request something of you."

Also, the expression of will (which is a constitutive feature of directives) can be supported (in fact, doubled) by combining of chtit / want with directive performative verbs:

(14) Chci se vás zeptat, kdy prijedete.

"I want to ask when will you arrive."

(15) Chci vás požádat o malou laskavost. 
"I want to request a little favour of you."

Similar enhancing can be seen in using chtit / want together with commissive performative verbs:

(16) Chci vám slíbit, že práci dokončím včas.

"I want to promise you that I will finish the work on time."

(17) Chci vám zaručit, že vašemu projektu bude věnována náležitá pozornost.

"I want to guarantee you that your project will get proper attention."

(18) Chci vás ujistit, že o řěsení podobných problémů bude postaráno.

"I want to assure you that solution of similar problems will be taken care of."

Formulation with mohu/I can and commissive performative verbs expresses one of the preliminary conditions of commissive speech acts (speaker's ability to do $(p))$ and they too represent enhancement of the illocutionary force:

(19) Mohu vám slíbit/ mohu vám zaručit, že už se to nestane.

"I can promise/guarantee you that it will not happen again."

Another variation of explicitenes can be see in construction with negated modals. They explicitly inform the addressee about speaker's communicative strategy denying either the necessity (nemusim / I don't need/have to) or speaker's intention to perform the illocutionary act in question:

(20) Nemusím vám zakazovat, abyste tam chodili

"I do not have to forbid you to go there."

(21) Nemusím vám slibovat, že v sobotu přijedu

"I need not to promise you that I will come on Saturday."

Utterances like (19) and (20) are mostly conntected with pragmatic presuppositions of the kind „,because I hope that you know that $(p)$ anyway“. On the other hand, strategy descriptions using the expression of will (chtit / want, hodlat / be going to) carry a presupposition of the speakers power or ability to perform the illocutionary act which is to be suppressed because of reluctance or consideration:

(22) Nechci / nehodlám vám zakazovat, abyste tam chodili. (Ale ...)

"I do not want / I am not going to forbid you to go there. (But ...)"

(23) Nechci vám slibovat, že v sobotu přijedu

"I do not want to promise you that I will arrive on Saturday."

An explicit statement that I do not have to or I do not want to forbid or promise something to the addressee can occur in a context where a prohibition or a promise is under discussion and where the relations of "speaker's will" and "addressee's will" are influenced by some other deontic modality (authority) - in that case the neustic of similar utterances is modified (lowered). The level of markedness of such utterances is weaker if the person who is forbidden from something or has promises made to him is not identical with the addressee. Examples like

(24) Nemusím mu zakázat/zakazovat, aby o tom mluvil.

"I do not have to /need not forbid him from speaking about it."

(25) Nechci jim zakázat/zakazovat, aby o tom mluvili.

"I do not want to forbid them from speaking about it."

simply inform the addressee about the situation and do not create or implicate any modifications of an indirect directive or commissive, that is, they are similar to hedges but cannot be considered "hedged performatives" (Frazer 1975). 
As mentioned above, another variation of speaker's strategy specification occurs in utterances in which indicative form of an illocutionary or a modal verb is replaced by conditional. (In examples (26)-(29) the English translation is only informative; similar formulations are non-standard.)

(26) Sázel bych se, že to nestihne; Chtěl bych se vsadit, že to nestihne.

"I would bet that he will not make it; I would like to bet that he will not make it."

(27) Doporučoval bych ti, abys mu nic neřikal.

"I would recommend you not to tell him anything."

(28) Radil bych vám, abyste s tím prodejem počkali.

"I would advise you to postpone the sale."

(29) Varoval bych vás, abyste se neukvapovali.

"I would warn you not to act overhastily."

If general, the use of conditional mood expresses relativization of speaker's communicative intention (illocutionary point) - conditionals represent, even though implicitly, apodosis. Therefore, their use is motivated by politeness conventions, cf. the difference between (14) and (15) and their variations:

(14') Chtěl bych se vás zeptat, kdy přijedete.

"I would like to ask you when will you arrive.

(15') Chtěl bych vás požádat o malou laskavost.

"I would like to request a little favour of you."

The specification here is targeted on suggesting the addresse the very idea of being polite towards him/her - the relativization does not change the illocutionary force itself.

A real limitation (restriction) of illocutionary force can be seen in utterances when the speaker formally asks the addressee a question about his/her ability to perform some action $(p)$ required by a directive (asking about one of the preliminary conditions is a typical feature of indirect directives):

(30) Mohu / mohl bych vás požádat, abyste mi pomohl s tím kufrem?

"Can I/could I ask you to help me with my suitcase?"

(31) Mohl bych / směl bych se vás zeptat, jak jste se tohle dověděl?

"Could I/could I dare to ask you how did you learn this?"

At the same time, relativization od speakers intentions concerning $(p)$ almost rules out using conditional in commissives - formulations like slibil bych vam /zaručil bych sel zavázal bych se (I would promise/I would guarantee/ I would take an obligation) are fully grammatical but as speech acts they explicitly make a commitment dependent on some further proposition, i.e. they do not perform it and warn the addressee that his/her interpretation must take this fact into account. Nevertheless, those formulations also can be seen as an expression of an effort to be as specific as possible.

In this paper we have tried to shed some light on the expressions of speakers' strategy aimed at being specific and, trying this way to avoid the consequences brought about by unintended inferences on the part of the addressee. In the examples above, we have tried to show utterances in which "what is meant" is identical with "what is said". Also, the mentioned variations of interaction of modal and illocutionary lexical items seem to challenge the concept of modal verbs as mere operators. At least from the viewpoint of pragmatics, when an illocutionary verb acts together with a modal, the semantics of a modal verb, however abstract, contribute to the total meaning of an utterance substantially including the fact that certain level of compatibility between the 
modal and the illocutionary verb is required. If Levinson describes the total meaning of an utterance as a "semiotic pie", then modal verbs can play specific roles on several layers of such a construct. The aforementioned strategies are not the only ones and, returning to the question in the title of this paper, more experimental testing would be in place. Which of course, opens an area for future research.

\section{References}

Frazer, Bruce 1975. Hedged Performatives. In:: Syntax and Semantics 3, Cole, P. Morgan, J.L. (eds.), 187-210. Academic Press : New York

Grice, Henry Paul 1975. Logic and Conversation. In: Syntax and Semantics 3, Cole, P., Morgan, J.L. (eds.), 41-58. Academic Press : New York.

Grice, Henry Paul 1991. Utterer's meaning, sentence-meaning and word-meaning. In:

Pragmatic. A reader, Davis, S. (ed.), 65-76. OUP: New York, Oxford

Hirschová, Milada 2005. Modal verbs and illocutionary constructions. In: : Modality in Slavonic languages. New perspectives, Hansen, B. - Karlík, P. (eds.), 351-360. München : Verlag Otto Sagner.

Horn, Laurence R. 2001. A Natural History of Negation. Stanford : CSLI Publications

Levinson, Stephen C. 1983. Pragmatics. Cambridge : CUP

Levinson, Stephen C. 2000. Presumptive Meanings. MIT Press : Cambridge (Mass.)

Lyons, John 1977. Semantics vol. 2. Cambridge : CUP

Searle, John Rogers 1979. Expression and Meaning. Studies in the Theory of Speech Acts.

CUP : Cambridge - London - New York - Melbourne

Wunderlich, Dieter 1976. Studien zur Sprechakttheorie. Suhrkamp: Frankfurt am Main 